\title{
THE ROLE OF THE INDONESIAN GOVERNMENT IN THE ERA OF BANKING DISRUPTION INNOVATION
}

\author{
Poni Sukaesih Kurniati \\ Government Studies Program, Universitas Komputer Indonesia, Bandung, Indonesia \\ Suryanto Suryanto \\ Department of Business Administration, Universitas Padjadjaran, Bandung, Indonesia
}

\begin{abstract}
Digital disruption innovation in the financial services industry is an innovation that has succeeded in changing the financial industry landscape, starting from its structure, technology, and marketing model. The emergence of the Financial Technology (Fintech) industry marks a disruptive innovation in the financial services industry. This study aims to analyze the role of the Indonesian government in the era of banking disruption. The research method used was descriptive analysis with a qualitative approach-data obtained through interviews and literature study, Bank Indonesia, the Indonesian Fintech Association, and the National Bank Association. Before the research started, the validity of the data was first tested. The results of the study state that the government encourages banking and fintech to grow side by side and is directed to collaborate immediately. The role of the government as a regulator has been performed by the Indonesian Financial Services Authority (OJK) and Bank Indonesia (BI, Central Bank of Indonesia) by issuing various regulations. The study concluded that there are three areas that regulators need to monitor and guard, including misuse of public funds, protection of the public, private data, and money laundering.
\end{abstract}

Keywords: Banking, Disruption, Fintech, Government Role

DOI: http://dx.doi.org/10.15549/jeecar.v9i1.881

\section{INTRODUCTION}

Disruptive innovation is an era of massive changes caused by innovations that change business systems and arrangements to newer levels (Kagermann, 2015). The banking industry is currently experiencing a period of disruptive innovation with the emergence of the financial technology industry. Banking must be more creative and innovative to survive the era of disruption. Not a few banks are losing money and are forced to close some of their branch offices because they are not ready to face competition in the era of disruption (Weill \& Woerner, 2015). Before it is too late, banks must recognize the era of disruption and find the right strategy to survive the competition. Disruption can occur in all types of banks if they do not innovate and transform. Banks that do not innovate and change will be abandoned by their consumers (Gomber et al., 2018). Technological developments can impact banking, including increasing productivity, saving costs, simplifying 
business processes, and providing better customer service (Savrul et al., 2014).

This wave of disruption allows new players to become the main players. Technology-based financial service companies, known as financial technology (fintech), can create new conditions in the financial services industry (Varga, 2017). The mature banking industry must accept that people's financial service needs are starting to be met by newcomers called fintech. Fintech should not only be considered as an alternative payment method but can also be applied as an innovation in the financial sector that provides more practical and secure financial transactions. This development can show that fintech can be a game-changer for financial businesses in Indonesia.

The presence of the fintech industry is considered a disruption to conventional financial institutions, services, and products. Currently, fintech is gaining momentum globally and disrupting traditional value chains. The fintech disruption has deeply affected the consumer banking and payment system sectors. The majority of respondents view that the consumer banking sector and the transfer of funds and payments are the sectors most disrupted by fintech in the next five years (PricewaterhouseCoopers, 2016). The era of banking disruption has affected the banking industry. It can be seen from the increasing number of banks closing their branch offices. There are several reasons that accelerate the disruption of the banking industry, including (1) the banking industry is very tightly regulated, while fintech is not strict, and (2) the banking industry is not as flexible as fintech, which can add features every two weeks. Banks have to face challenges because every activity must go through a Bank Business Plan (RBB) report, which is made once a year and can only be changed every six months.

Previous research related to disruptive innovation has focused more on the impact of fintech on banking and the transformation carried out by the banking industry. Weill \& Woerner (2015) and Kaur et al. (2021) state that the increase in digital banking innovation has made some banks reduce the number of branches. PricewaterhouseCoopers (2016) concluded that banking institutions are worried that their consumers will be snatched away by fintech. Kennedy \& Harefa (2018) state that the presence of the fintech industry can damage the banking sector, and there is a possibility that bank performance can be disrupted. This research is supported by Suryanto et al. (2020), who stated that fintech has more support from the community because of the ease of transaction processing compared to banking. Gupta et al. (2018) carried out different research results, which stated that the banking system had undergone changes after launching mobile banking applications, internet banking, ATMs, and electronic payment systems. Githuku \& Kinyuru (2018), in their research, stated that Smartphones and the internet had become digital banking service channels as bank survival, through the advantages of convenience, can be accessed anytime and anywhere. While the results of research by Brennen \& Kreiss (2016) and Scott et al. (2017) explore the impact of using technology and information on the production of bank services, namely cost savings, labor, and capital savings.

Based on previous research, no one has examined the role of government in the era of banking disruption. This research is required because the banking industry must continue to grow and even complement the fintech industry to meet the needs of public financial services. This study aims to analyze the role of the government in the era of banking disruption. The research method used in this research was descriptive analysis with a qualitative approach.

\section{LITERATURE REVIEW}

\section{Banking Disruptive Innovation}

It is challenging to pinpoint precisely when this disruptive innovation first appeared globally. However, disruptive innovation was popularized in 1995 in the Harvard Business Review (Bower \& Christensen, 1995) and published in The Innovator's Dilemma (Christensen, 2013). Discussions about this theory have only emerged recently. Disruptive innovation has transformed an existing system or market by introducing practicality, ease of access, convenience, and economic costs (Bower \& Christensen, 1995). Disruptive innovations usually take specific market segments that are less desirable or considered less important for market leaders. Still, the inventions are breakthroughs and can redefine existing systems or markets. The emergence of disruptive innovations, if not anticipated by the business world, can lead to 
downfall (Hadad, 2017). Disruptive innovation offers a disruptive technology or an innovation that can beat old concepts (Christensen, 2013). The technology provided includes more exclusive features, lower costs, and easier access.

Disruptive innovation can occur in almost all business sectors. Disruptive innovation also appears in the financial services industry, which has disrupted the global financial services industry landscape (Gomber et al., 2018). Disruption in the financial industry occurs starting from its industrial structure, intermediation technology to its marketing model to consumers. The impact of the disruption in the financial services sector gave rise to new financial services known as financial technology (Chiu, 2017).

Financial technology (fintech) offers services traditionally offered by banks (Bezhovski, 2016). However, fintech can provide solutive financial services using technology (Arner et al., 2015). In addition, fintech can also mediate financial problems (Aaron et al., 2017). Fintech also promises a new ecosystem for the financial industry at low costs, improving the quality of financial services, and creating a more diverse and stable financial landscape (Lee et al., 2018).

Two factors drive fintech to grow rapidly: shifting consumer preferences and technological evolution (Awrey, 2013); (De Haan et al., 2020). The first factor is the shift in consumer preferences that affect consumer demand for innovation. Easy internet access and the ability of internet network users to make real-time transactions have driven high expectations, especially regarding convenience, speed, lower costs, and ease of use of financial services. In addition, changes in preferences also occur due to the influence of demographic factors that drive demand, such as increased acceptance from groups who have grown up with digital technology (digital natives) and millennials. The second factor, the evolution of technology in financial services, is developing rapidly and in new ways and utilizing different business models. For example, business models using big data technology, artificial intelligence (AI), machine learning, cloud computing, and biometrics. Apart from this, new technologies have also been applied (He et al., 2017); (Griffoli, 2017).

\section{Regulation and Government}

Innovation is an alternative that offers efficiency and practicality (Guttentag, 2015). Innovation is a new technological invention that has never existed before. Thus, these innovations certainly do not have rules that stipulate how the technology should work like fintech, resulting from innovation in the financial industry. The existence of fintech services can provide flexibility, transparency, efficiency, and simplicity.

It is feared that various financial services provided by fintech will disrupt the banking industry (Hassan et al., 2020). It is based on the fact that the fintech industry has similar financial services. In addition, the fintech industry is also widely liked by the public because it can provide practical solutions to financial service problems. The government as a regulator is the hope of the fear of conflict between the banking industry and fintech (Brummer, 2015).

The role of regulators and interested parties certainly needs to sit down together to discuss policies that will be made that can protect all parties. The government needs to make regulations that contain four main elements. These elements include being neutral, adaptable, collaborating with other parties, and having universal dimensions (Panetta, 2018).

\section{METHOD}

This study used a descriptive analysis method with a qualitative approach. This method was chosen to gain a basic understanding through first-hand experience from researchers who directly processed and merged into an inseparable part of the subject and set to be studied. Primary data sources were obtained from in-depth interviews, while secondary data were obtained from research results. Interviews were conducted with key informants from the Financial Services Authority, Bank Indonesia, the Indonesian Fintech Association, and the National Banking Association. The data that has been obtained was tested for validity by using triangulation.

The data that has been collected were analyzed using descriptive analysis techniques. Descriptive analysis is intended to make a description of situations or events. The report or information about the event or object that emerged from the field notes was reviewed by 
considering the degree of internal coherence, making sense, and relating to factual and realistic circumstances.

\section{RESULTS AND DISCUSSION \\ Banking Challenges in the Age of Digital Disruption}

The era of digitalization has disrupted the banking sector from being offline to online. Conventional banking transactions, which are generally carried out directly, are starting to be abandoned because they are less relevant to the needs of today's society. This condition requires banks to think hard to adapt and survive in the midst of changing digital markets. This change is a challenge for the banking industry with the presence of a new player in the financial industry, namely financial technology (fintech). Fintech is experiencing rapid development in Indonesia and is predicted to become a tough competitor for the banking industry. It happens because fintech offers financial products or services with various conveniences (Suryanto et al., 2020).

The era of banking digitalization, known as digital banking 4.0, is an opportunity for banks to be more innovative in providing services to customers. These innovations are needed to respond to the competition along with the rapid growth of fintech. Banking digitalization makes it easy for customers to process all their banking product and service needs online, from account opening, financial transaction execution to account closing. In response to this, the banking industry is aggressively migrating banking services from conventional to digital. This digital service optimization was carried out as a quick response due to the decline in direct banking transactions. The acceleration of banking digitalization is also intended to increase the efficiency of banking services and save operational costs (Auta, 2010). In addition, to be able to reach more customers and increase competitiveness between the banking industry and across industries in the midst of unlimited competition.

However, there are several challenges for banks that are transforming to digital:

1. The most severe challenge is infrastructure. Infrastructure is an obstacle if you want to reach consumers outside the city.
2. Socialization to the community, especially in rural areas, to understand digitalization, the use of smartphones, mobility, and the threat of fraud.

3. Many banks find it challenging to enter digitization because they are burdened with the thought of capital expenditure. In addition to these challenges, the acceleration of banking digitalization has also triggered various crucial issues in society.

4. The acceleration of banking digitalization by increasing employee efficiency increases the unemployment rate in Indonesia.

Especially now that many banks have closed their branch offices to reduce operational costs and provide digital services. Data on the decline in banks and bank branch offices during the period December 2020 to March 2021 are shown in Table 1.

Table 1: Number of Banks and Branch Offices

\begin{tabular}{|l|l|l|l|}
\hline No & Period & $\begin{array}{l}\text { Bank } \\
\text { Amount }\end{array}$ & $\begin{array}{l}\text { Number of } \\
\text { Branch } \\
\text { Offices }\end{array}$ \\
\hline 1 & $\begin{array}{l}\text { December } \\
2020\end{array}$ & 109 & 29.889 \\
\hline 2 & $\begin{array}{l}\text { March } \\
2021\end{array}$ & 107 & 30.733 \\
\hline
\end{tabular}

Source: (OJK, 2021)

Based on Table 1, it can be seen that there was a decrease in the number of bank branch offices by 844 during the period December 2020 to March 2021. The decline in branch offices was also in line with the decrease in the number of banks from 109 to 107. In fact, in the past six years, more than 3,000 branch offices have been closed. The banks that closed branch offices were Bank Mandiri, Bank BNI, Bank BRI, Bank BTN, BCA, Bank Permata, and Bank Panin.

Second, the high potential for data leakage or theft in digital transactions by unknown and irresponsible individuals from external and internal to the Bank itself. Considering the task of banking is to collect public funds so that it is prone to crime, especially not all customers are proficient in using digital banking services. It is in accordance with what was stated (Ranglin \& 
Taussig, 2019), which stated three critical aspects for database businesses such as banks: data privacy, data security, and cyber security. At this level, banks must educate customers by conducting socialization as creatively as possible and providing notifications or warnings to customers on an ongoing basis. It is to increase awareness of customers' responsibilities in maintaining the security of their assets and personal data while using digital banking services.

Third, the model of cybercrime in the era of digitalization of banking is getting higher. Even the speed of hackers today cannot be predicted by anyone. This condition has the potential for fraud committed by deceiving customers until customer funds disappear. Moreover, regulations regarding cyber security in Indonesia are still weak, thus placing customers as service consumers who are often disadvantaged. Therefore, banks that automate digital services must strengthen digital banking security and ensure asset protection and customer personal data protection.

\section{The Role of Government in the Era of Banking Disruption}

The growth of the fintech industry is not to eliminate the role of banks in the financial services sector. The role of banking is believed to still exist by collaborating with fintech. Banks continue to carry out their roles on the condition that they must carry out transformations. Five possibilities can happen to the Bank in the era of disruptive innovation. First, the possibility of banking can be better with the advancement of information technology. The condition is that banks can adapt and transform. Therefore, they can attract more customers with digital services. Second, the current banks cannot adapt and are left behind. However, at the same time, new banking companies will emerge whose business processes have adopted digital technology and are widely used by customers. The third is a scenario where conventional banks continue to carry out general activities and maintain relationships with customers. However, there will be special services that digital-based companies will provide. Fourth, banking companies will be degraded. Furthermore, they will only carry out general activities. Meanwhile, other relationships and coaching with customers will be carried out by more digital companies.
The last scenario is that banks no longer act as intermediaries because people who use the financial services sector can directly interact with companies that have been digitized.

Disruptive innovations in the banking industry need intervention from the government as a regulator. The banking industry can still develop amidst the booming growth of the fintech industry. Banks can collaborate with the fintech industry. Collaboration that can be carried out, among others, is in the form of platform sharing, infrastructure sharing, and product distribution and offerings. Bank collaboration with fintech will provide opportunities to increase product innovation and increase product distribution channels to the public. The advantage of collaborating with fintech for banks is that it is easier to create product innovations that are in accordance with community desire. Meanwhile, customers will experience a different experience because of the ease of obtaining financial services from banks and fintech that can be done in one application. In comparison, the benefits for the economy can increase financial inclusion in Indonesia and facilitate financial access to MSMEs.

The role of the government is urgently needed so that banking and fintech can grow side by side and even encourage collaboration as soon as possible. As the regulator, the government's role has been carried out by OJK and Bank Indonesia by issuing various regulations. As a regulator, the rules made as described by Panetta (2018) must contain four main principles:

1. Regulators must be neutral to avoid supervisory arbitrations.

2. It must be adaptable, given the rapid changes that will impact fintech in the future.

3. The collaboration of financial sector authorities with regulators is vital in other areas such as data protection, cyber risk, and antitrust.

4. The regulation must also have a universal dimension to deal with global developments in technology and the financial services market.

Following its authority, as regulated in Law No 21/2011, 2011, OJK has prepared several rules to regulate and supervise the development of types of businesses in the financial services 
sector. OJK was established to ensure that all activities in the financial services sector are organized in an orderly, fair, transparent, accountable manner and can realize a financial system that grows sustainably and stably and can protect the interests of consumers and the public.

OJK has issued regulations relating to the transformation of banking to digital banks. OJK Regulation No 12/POJK.03/2021 concerning Commercial Banks regulates banking to spur the digital bank transformation process to become more firm, clear, definite, and on target. The OJK regulation is based on the spirit and purpose so that Indonesian banks can become more competitive, adaptive, and contributive to the national economy. The regulation also aims to encourage the banking industry to reach a higher level of economies of scale, be more efficient, and serve as a guide in the development of the banking industry, particularly related to bank institutional aspects. In general, the regulations in the OJK Regulation concerning Commercial Banks apply to conventional commercial banks, namely Banks with Indonesian Legal Entities and Branch Offices of Banks Domiciled Abroad, as well as regulations for Representative Offices of Banks Domiciled Abroad.

OJK also issued OJK Regulation No 13/POJK.03/2021 concerning the Implementation of Commercial Bank Products. The regulation is expected to enhance bank competitiveness through a faster-licensing process further and prioritizing risk management. Bank Products are business activities carried out by Banks to provide products, services, and services for the benefit of customers. The obligation to implement risk management for the effective operation of Bank Products and the responsibility of the Bank to ensure the creation of convergence in the operation of Bank Products.

Then OJK also issued OJK Regulation No. 14/POJK.03/2021 as an amendment to OJK Regulation No. 34/POJK.03/2018, concerning Reassessment of Main Parties of Financial Services Institutions. The three regulations issued by OJK are believed to spur the digital bank transformation process to become more firm, clear, definite, and on target. The issuance of the three new regulations is predicted to make banking consolidation steps more agile. For banking groups with significant capital, the issuance of this regulation is welcomed with joy because the transformation process to digital banking is without problems. However, for small banks whose capital scale tends to be limited, the transformation process to digital banking is a challenge.

Financial technology (fintech) in the financial system can produce new products, services, and business models. The development of fintech, on the one hand, has proven to bring benefits to consumers, business actors, and the national economy, but on the other hand, it has potential risks. If these risks are not adequately mitigated, they can disrupt the monetary and financial systems.

Through Bank Indonesia Regulation No.19/12/PBI/2017, Bank Indonesia regulates registration requirements at Bank Indonesia for Financial Technology Operators conducting payment system activities. The registration obligation is excluded for payment system service providers who have obtained permission from Bank Indonesia and for fintech operators under the authority of other authorities. Furthermore, Bank Indonesia will announce fintech providers that have been registered on the official website of Bank Indonesia. The registration obligation does not eliminate the fintech Operator's obligation to apply for a license to Bank Indonesia or the relevant authorities.

Bank Indonesia has also issued a regulation regarding the fintech Regulatory Sandbox, which clearly regulates the trial procedures and processes. Bank Indonesia has carefully followed and explored the development of technological innovation in financial services offered by fintech. Bank Indonesia established the BI-FTO (BI - Fintech Office) to maintain the playing field level through balanced and proportional regulations without having to turn off the pace of innovation.

Bank Indonesia released new rules regarding electronic money through Bank Indonesia Regulation No.20/6/PBI/2018. This regulation is a revision of the previous code, namely Bank Indonesia Regulation No. 18/40/PBI/2016. The increasingly varied electronic money business model and the high increase in transaction value have prompted Bank Indonesia to regulate this business more stringently. Non-Bank Institutions applying for licenses as Issuers must meet the 
minimum paid-up capital requirements and share ownership composition.

\section{CONCLUSION}

Technological developments have disrupted the banking industry with the presence of the financial technology industry. Banks carry out digital transformation to survive the competition between banks and the fintech industry. However, there are several challenges faced by banks in carrying out digital transformation. Apart from internal banking, challenges also arise from external parties. As a regulator, the government expects the banking industry to grow and collaborate with the fintech industry. Collaboration can provide benefits to both institutions, consumers and can stimulate economic growth.

\section{REFERENCES}

Aaron, M., Rivadeneyra, F., \& Sohal, S. (2017). Fintech: Is this time different? A framework for assessing risks and opportunities for central banks. Bank of Canada Staff Discussion Paper.

Arner, D. W., Barberis, J., \& Buckley, R. P. (2015). The evolution of Fintech: A new post-crisis paradigm. Geo. J. Int'l L, 47, 1271.

Auta, E. M. (2010). E-banking in developing economy: Empirical evidence from Nigeria. Journal of Applied Quantitative Methods, $5(2)$.

Awrey, D. (2013). Toward a supply-side theory of financial innovation. Journal of Comparative Economics, 41(2), 401-419. https://doi.org/10.1016/j.jce.2013.03.011

Bezhovski, Z. (2016). The Future of the Mobile Payment as Electronic Payment System. European Journal of Business and Management, 8(8), 127-132.

Bower, J. L., \& Christensen, C. M. (1995). Disruptive technologies: catching the wave. Harvard Business Review. https://hbr.org/1995/01/disruptivetechnologies-catching-the-wave

Brennen, J. S., \& Kreiss, D. (2016). Digitalization. The International Encyclopedia of Communication Theory and Philosophy, 1-11. https://doi.org/10.1002/9781118766804.wbiect 111
Brummer, C. (2015). Disruptive technology and securities regulation. Fordham L. Rev., 84, 977.

Chiu, I. H. (2017). he disruptive implications of fintech-policy themes for financial regulators. Technology Law \& Policy, 21(1).

Christensen, C. M. (2013). The innovator's dilemma: when new technologies cause great firms to fail. Harvard Business Review Press.

De Haan, J., Schoenmaker, D., \& Wierts, P. (2020). Financial markets and institutions: A European perspective. Cambridge University Press.

Githuku, W. A., \& Kinyuru, R. N. (2018). Digital banking and customer relationship in banking industry in Kenya. International Academic Journal of Human Resource and Business Administration, 3(2), 14-32.

Gomber, P., Kauffman, R. J., Parker, C., \& Weber, B. W. (2018). On the fintech revolution: Interpreting the forces of innovation, disruption, and transformation in financial services. Journal of Management Information Systems, 35(1), 220-265. https://doi.org/10.1080/07421222.2018.144 0766

Griffoli, T. M. (2017). Banking on change: New technologies promise to reshape the financial services industry. Finance \& Development, 54(003). https://doi.org/10.5089/9781484315972.02 2

Gupta, S. D., Raychaudhuri, A., \& Haldar, S. K. (2018). Information technology and profitability: evidence from Indian banking sector. International Journal of Emerging Markets. https://doi.org/10.1108/IJoEM-06-20170211

Guttentag, D. (2015). Airbnb: disruptive innovation and the rise of an informal tourism accommodation sector. Current Issues in Tourism, 18(12), 1192-1217. https://doi.org/10.1080/13683500.2013.827 159

Hadad, M. D. (2017). Financial Technology (Fintech) di Indonesia. In Kuliah Umum tentang Fintech, Indonesia Banking School.

Hassan, M. K., Rabbani, M. R., \& Ali, M. A. M. (2020). Challenges for the Islamic Finance and banking in post COVID era and the role 
of fintech. Journal of Economic Cooperation \& Development, 41(3), 93-116.

He, M. D., Leckow, M. R. B., Haksar, M. V., Griffoli, M. T. M., Jenkinson, N., Kashima, M. M., Khiaonarong, T., Rochon, M. C., \& Tourpe, H. (2017). Fintech and financial services: initial considerations. International Monetary Fund.

Kagermann, H. (2015). Change through digitization-Value creation in the age of Industry 4.0. In Management of permanent change (pp. 23-45). Springer. doi: 10.1007/978-3-658-05014-6_2

Kaur, S. J., Ali, L., Hassan, M. K., \& Al-Emran, M. (2021). Adoption of digital banking channels in an emerging economy: exploring the role of in-branch efforts. Journal of Financial Services Marketing, 26(2), 107-121 https://doi.org/10.1057/s41264-020-00082-w

Kennedy, P. S. J., \& Harefa, A. A. (2018). The Financial Technology, Regulation and Banking Adaptation In Indonesia. Fundamental Management Journal, 3(1), 1-11.

Lee, J., Li, T., \& Shin, D. (2018). The wisdom of crowds in FinTech: Evidence from Initial Coin Offerings. SSRN Electronic Journal, 142. https://doi.org/10.2139/ssrn.3195877

OJK. (2021). Momentum stabilitas pemulihan ekonomi nasional.

Panetta, F. (2018). Fintech and Banking : today and tomorrow.

PBI No. 18/40/PBI / 2016. (2016). Penyelenggaraan Pemrosesan Transaksi Pembayaran. Bank Indonesia.

PBI No.19/12/PBI/2017. (2017). Penyelenggaraan Teknologi Finansial. Bank Indonesia.

PBI No.20/6/PBI/2018. (2018). Uang Elektronik. Bank Indonesia.

POJK No. 14/POJK.03/2021. (2021). Perubahan atas POJK No. 34/POJK.03/2018 tentang Penilaian Kembali Pihak Utama Lembaga Jasa Keuangan. Otoritas Jasa Keuangan.

POJK No. 34/POJK.03/2018. (2018). Penilaian Kembali Bagi Pihak Utama Lembaga Jasa Keuangan. Otoritas Jasa Keuangan.

POJK No 12/POJK.03/2021. (2021). Bank Umum. Otoritas Jasa Keuangan.

POJK No 13/POJK.03/2021. (2021). Penyelenggaraan Produk Bank Umum. Otoritas Jasa Keuangan.
PricewaterhouseCoopers (PwC). (2016). How fintech is shaping financial service. Global FIntech Report.

Ranglin, C., \& Taussig, S. (2019). Data Policy Operating Definition. Kabbage, Inc.

Savrul, M., Incekara, A., \& Sener, S. (2014). The potential of e-commerce for SMEs in a globalizing business environment. ProcediaSocial and Behavioral Sciences, 150, 35-45. https://doi.org/10.1016/j.sbspro.2014.09.005

Scott, S. V, Van Reenen, J., \& Zachariadis, M. (2017). The long-term effect of digital innovation on bank performance: An empirical study of SWIFT adoption in financial services. Research Policy, 46(5), 984-1004. https://doi.org/10.1016/j.respol.2017.03.010

Suryanto, Rusdin, \& Dai, R. M. (2020). Fintech as a catalyst for growth of micro, small, and medium enterprise in Indonesia. Academy of Strategic Management Journal, 19(5), 1-12.

Undang-Undang No 21/2011. (2011). Otoritas Jasa Keuangan. Kementerian Hukum dan HAM Republik Indonesia.

Varga, D. (2017). Fintech, the new era of financial services. Vezetéstudomány-Budapest Management Review, 48(11), 22-32. https://doi.org/10.14267/VEZTUD.2017.11.03

Weill, P., \& Woerner, S. L. (2015). Optimizing your digital business model. MIT Sloan Management Review, 53(3), 28-36.

\section{ABOUT THE AUTHORS}

Poni Sukaesih Kurniati, email: poni.sukaesih@email.unikom.ac.id

Poni Sukaesih Kurniati, Government Studies Program, Faculty of Social and Political Sciences, Universitas Komputer Indonesia, Bandung, Indonesia.

Suryanto Suryanto, Department of Business Administration, Universitas Padjadjaran, Bandung, Indonesia. 